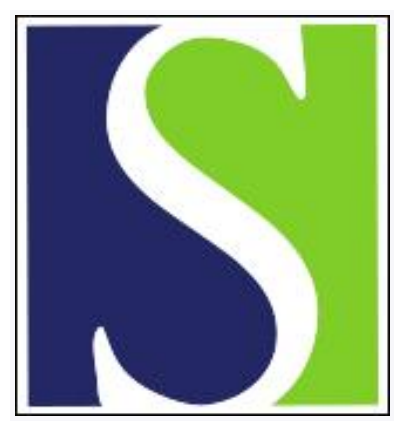

Scand J Work Environ Health 1989;15(5):339-344

https://doi.org/10.5271/sjweh.1840

Issue date: Oct 1989

Finger receptor dysfunction in dental technicians exposed to high-frequency vibration.

by Hjortsberg U, Rosen I, Orbaek P, Lundborg G, Balogh I

Affiliation: Department of Occupational Medicine, Malmo General Hospital, Sweden.

The following article refers to this text: 2011;37(3):244-252

This article in PubMed: www.ncbi.nlm.nih.gov/pubmed/2799321

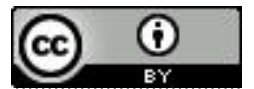




\title{
Finger receptor dysfunction in dental technicians exposed to high-frequency vibration
}

\author{
by Ulf Hjortsberg, MD, ${ }^{1}$ Ingmar Rosén, MD, ${ }^{2}$ Palle Ørbæk, MD, ${ }^{1}$ Göran Lundborg, MD, ${ }^{3}$ \\ Istvan Balogh, MSc, ${ }^{4}$
}

\begin{abstract}
HJORTSBERG U, ROSÉN I, ØRBAEK P, LUNDBORG G, BALOGH I. Finger receptor dysfunction in dental technicians exposed to high-frequency vibration. Scand $J$ Work Environ Health 1989;15:339-344. The effects of high-frequency vibration (up to $40 \mathrm{kHz}$ ) on digital nerve function were studied in ten dental technicians and ten age-matched referents. Nerve conduction velocities, including fractionated antidromic measurements over the carpal tunnel, showed no difference between the groups. In the group of dental technicians the difference between the response latency of the mechanical and electric stimuli in the median nerve distally on the fingers of the right hand was slightly higher than in the reference group, and therefore distal nerve or receptor dysfunction was suggested. Vibration warming and cooling thresholds were significantly increased and thus revealed damage to both myelinated and unmyelinated fibers in the fingers of subjects exposed to high-frequency vibration.
\end{abstract}

Key terms: carpal tunnel syndrome, fractionated sensory nerve conduction, high-speed grinding, neuropathy, tactile-electric difference, temperature threshold, vibration threshold, vibrogram.

Dental technicians often complain of numbness, paresthesia, and pain in the hands. By working with high-speed grinding machines, they are exposed to high-frequency vibration up to $40 \mathrm{kHz}$. Dentists and ultrasonic therapists exposed to high-frequency vibration from ultrahigh-speed handpieces have been shown to acquire a deficient vibration perception $(1,2)$.

Long-lasting exposure to lower frequency vibration from drills, chipping hammers, and grinding machines in the mechanical industry and workshops and from chain saws among lumberjacks often induces neuropathic signs in the hands $(3,4)$. In such subjects abnormal hand and finger perception can be demonstrated for vibration $(5,6)$ and other modalities such as temperature (6-8). Epidemiologic studies have suggested an increased risk of carpal tunnel syndrome among vibration-exposed workers (9-11). Electrophysiological studies have shown defects in nerve conduction as far proximal as the carpal tunnel in such patients (unpublished observations). The pathophysiological mechanisms behind these effects are still unclear. Low-frequency vibration is transmitted proximally from the area of skin contact with the handheld tool and might produce damage to nerves through swelling of the endoneurium and impaired microcir-

1 Department of Occupational Medicine, Malmö General Hospital, Malmö, Sweden.

2. Department of Clinical Neurophysiology, Malmö General Hospital, Malmö, Sweden.

3 Department of Hand Surgery, University of Lund. Malmö General Hospital, Malmö, Sweden.

4 Departments of Occupational Medicine and Industrial Management \& Working Environment, University of Lund, Lund, Sweden.

Reprint requests to: $\mathrm{Dr} \mathrm{U}$ Hjortsberg, Yrkesmedicinska kliniken, Allmänna sjukhuset, S-214 01 Malmö, Sweden. culation, as suggested from our experimental work (12). With high-frequency vibration the mechanical energy is absorbed in the skin; thus no proximal nerve damage is expected.

The purpose of our study was to investigate distal sensory perception and nerve conduction in the hands of dental technicians exposed for a long time to highfrequency vibration. Our hypothesis was that the highfrequency vibration might interfere with the function of the distal nerve endings and receptors but should not affect the more proximal digital nerve fibers.

\section{Subjects and methods}

Subjects

Ten men between 26 and 62 (mean 44) years of age who had worked as dental technicians for 7 to 43 (mean 27) years participated in the study. Most of the dental technicians complained about paresthesia and numbness of the hands. According to the sensorineural staging proposed in Stockholm in 1986 (5), two were in stage 0 , lacking sensorineural finger symptoms; six were in stage 1 , having intermittent numbness; one was in stage 2, having persistent numbness; and one was in stage 3, with reduced manipulative dexterity. Staging of their vascular reactivity according to the revised Taylor-Pelmear scale (13) revealed six subjects in stage 0 , having no attacks of finger blanching; two in stage 1, having occasional blanching attacks affecting the fingertips; and two in stage 3 , having frequent attacks of all phalanges of most fingers. The temperature recovery time after hand cooling was abnormal for four subjects and normal for six (table 1).

In parallel, identical examinations with the same equipment were made on 10 age-matched healthy men 
Table 1. Vascular and sensory disturbance in 10 dental technicians.

\begin{tabular}{lccl}
\hline $\begin{array}{l}\text { Age } \\
\text { (years) }\end{array}$ & $\begin{array}{c}\text { Taylor- } \\
\text { Pelmear } \\
\text { stage }^{a}\end{array}$ & $\begin{array}{c}\text { Sensori- } \\
\text { neural } \\
\text { stage }^{b}\end{array}$ & $\begin{array}{l}\text { Skin temperature } \\
\text { recovery } \\
\text { time }^{\text {c }}\end{array}$ \\
\hline 26 & 0 & 0 & Normal \\
33 & 1 & 0 & Abnormal \\
38 & 0 & 2 & Normal \\
38 & 0 & 1 & Abnormal \\
41 & 3 & 1 & Abnormal \\
48 & 1 & 1 & Normal \\
49 & 0 & 1 & Normal \\
51 & 0 & 3 & Normal \\
56 & 0 & 1 & Normal \\
62 & 3 & 1 & Abnormal \\
\hline
\end{tabular}

a Taylor-Peimear revised stages: $0=$ no attacks, $1=$ occasional attacks affecting only the tips of one or more fingers, $2=$ occasional attacks affecting the distal and middle phalanges of most fingers, 3 = frequent attacks affecting all phalanges of most fingers.

b Sensorineural stages: $0=$ no symptoms, $1=$ intermittent numbness with or without tingling, 2 =intermittent or persistent numbness, reduced sensory perception, $3=$ intermittent or persistent numbness, reduced tactile discrimination and/or manipulative dexterity.

c Skin temperature recovery time after cooling of the hand in water $\left(15^{\circ} \mathrm{C}\right)$ and indirect skin warming and oral intake of 5 $\mathrm{ml}$ of $30 \%$ ethanol.

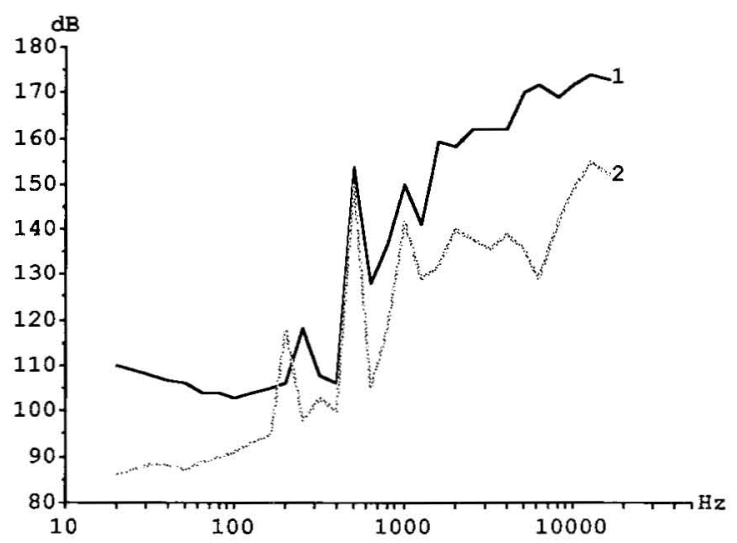

Figure 1. One-third octave spectrum of a workpiece (number 1) and a handheld high-speed grinder at 30000 revolutions/ $\mathrm{min}$ (number 2).

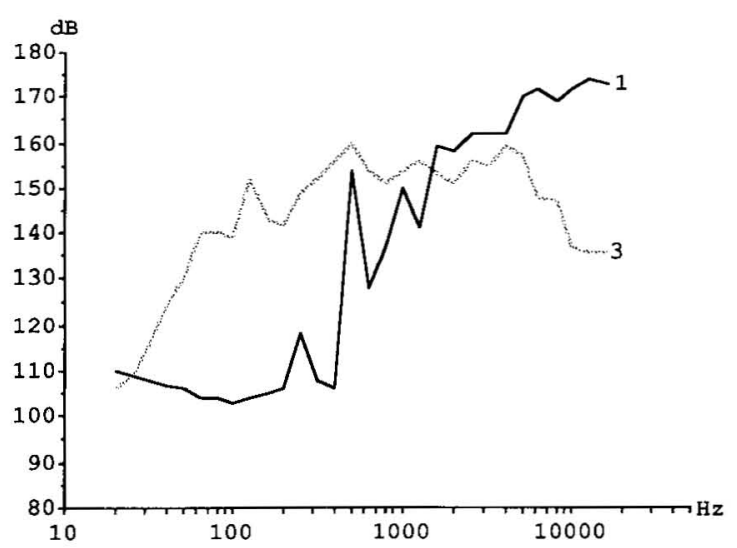

Figure 2. Typical one-third octave spectrum of the handheld workpiece shown in figure 1 (number 1 ) in comparison with a low-speed grinder at 7000 revolutions/min (number 3 ). lacking symptoms from their hands and without occupational exposure to vibration.

\section{Exposure}

All the exposed subjects worked for $2-6 \mathrm{~h}$ /workday with high-frequency grinding equipment. They all were professionally active at the time of the investigation but had not been exposed to vibration on the examination day, when testing was made between 1300 and 1400.

During the last 30 years grinding equipment has become more efficient through increases in speed from 15000 to 30000 revolutions/min. All the exposed subjects worked with high-speed grinders; eight were specialized in grinding Vitallium ${ }^{(p)}$ skeleton.

Measurements on drills and work objects were made with a small accelerometer (Brüel \& Kjær 4374) glued to the object. Because of the need for a dynamic range of $100 \mathrm{~dB}$, the measurements were made in one onethird octave at a time (Brüel \& Kjær 1616\& 2209). The results were confirmed with a fast fourier transform analyzer (Brüel \& Kjær 2033). Furthermore frequencyweighted acceleration levels were measured according to the standard of the International Organization for Standardization (ISO) (Brüel \& Kjær 2513) (14).

Vibration exposure arose not only from the handheld grinders, but also from the handheld workpiece (figure 1). The weighted accelerations (ISO 5349) were $2-4 \mathrm{~m} / \mathrm{s}^{2}$. Above $1.2 \mathrm{kHz}$ the accelerations ranged from 3 to $500 \mathrm{~m} / \mathrm{s}^{2}(130-175 \mathrm{~dB})$. Comparison with a low-speed grinder is shown in figure 2 .

\section{Neurophysiological methods}

The sensory nerve conduction velocity in the median nerve was measured in the forearm, across the carpal tunnel, and from the palm to the middle finger with an antidromic technique (15, unpublished observations). The nerve response was recorded with ring electrodes around the proximal and distal interphalangeal joints (active electrode proximal). The nerve was stimulated with surface electrodes at the elbow, $2 \mathrm{~cm}$ proximal to the wrist crease, and in the palm.

The thresholds for warming and cooling were determined separately with Thermotest ${ }^{\text {"W' }}$ (Somedic Inc) equipment with a base-line temperature of the Peltier element of $30^{\circ} \mathrm{C}$. The subject was instructed to push a button at the earliest sensation of either warmth or cold. The changes in temperature were plotted, and the threshold was determined from the written curve of several trials. The fingertips of digits II and V were tested bilaterally.

Vibration thresholds were determined for the same fingertips with vibrameter equipment (Somedic Inc) (16). The probe vibrating at $100 \mathrm{~Hz}$ was placed onto the volar surface of each finger, which was resting on a pad filled with rice. The values have been expressed as vibration amplitudes $(\mu \mathrm{m})$ and are averages of thresholds to increasing and decreasing amplitudes of vibration in repeated trials. 
The timing of nerve impulse generation in the distal nerve terminals was determined by the difference in latency between the mechanical and electrical stimulation of tactile afferents from the fingertip of digit III (17). The action potentials of the sensory nerve were recorded with surface electrodes over the median nerve at the wrist. Electrical stimulation (duration $0.2 \mathrm{~ms}$ ) was applied with a wire electrode around the nail root (cathode) and around the fingertip $1 \mathrm{~cm}$ more distally (anode). Mechanical stimulation was applied with a tactile stimulator (Somedic Inc) delivering brief mechanical pulses (amplitude $800 \mu \mathrm{m}$, rise time 500 $\mu \mathrm{m} / \mathrm{ms}$, duration $10 \mathrm{~ms}$ ) to the nail of the same finger. A neurographic device (Medelec 92B) was triggered from the tactile stimulator, and 100 traces were averaged. The latency difference between the responses recorded with tactile and electrical stimulation (T-E difference) was calculated for each subject.

From the 10 dental technicians, vibrograms were also made according to the method described by Lundborg et al (18). The differences between the exposed and unexposed groups were evaluated with Wilcoxon's test for paired data. Associations were tested with the Spearman Rank correlation test.

\section{Results}

The results of the neurographic tests are summarized in table 2 , and the results of the perception tests for vibration and temperature are presented in table 3. There was no indication of any interference with nerve conduction at any segment of the median nerve in the exposed group. The conduction velocity across the carpal tunnel was even somewhat higher in the exposed group than in the referents.

In contrast with the conduction velocities, there were consistent differences between the exposed subjects and the referents in the perception of all three sensory modalities tested (table 3 ). The differences were slightly greater for the right hand than for the left, and for vibration and warming the changes were greater for digit II than for digit $\mathrm{V}$.

The T-E differences showed an increase for the right hand (table 2). The difference did not, however, reach the level of formal statistical significance $(P=0.056)$. No difference was found for the left hand.

The distribution of values obtained for the four discriminating variables for digit II of the right hand are shown in figure 3 . There was a large overlap of values between the exposed subjects and the referents, and the best separation can be seen for vibration, eight exposed subjects being outside the normal range, and for cooling, five subjects being outside the normal range.

The vibrogram examination showed marked abnormality (stage 3 ) in three subjects, slight abnormality (stage 1) in three, and normal curves for four. There was a slight correlation between the vibration threshold and vibrogram abnormality for digit II [Spearman rank regression coefficient $\left(\mathrm{r}_{\mathrm{s}}\right) 0.50$ [not significant (NS)] and $0.55(\mathrm{P}=0.05)$, respectively $\}$ but not for digit $\mathrm{V}$.

There was some association between the years of work as a dental technician and the vibration thresholds $\left[r_{\mathrm{s}} 0.52(\mathrm{NS})\right.$ and $\mathrm{r}_{\mathrm{s}} 0.77(\mathrm{P}<0.01)$ for right digits II and $\mathrm{V}$, respectively; $r_{s} 0.55(\mathrm{P}<0.05)$ and $r_{\mathrm{s}}$ $0.80(\mathrm{P}<0.01)$ for left digits II and $\mathrm{V}$, respectively]. However, age was significantly intercorrelated with the vibration thresholds and exposure time.

No significant correlation between vibrogram abnormality and years of exposure was found $\left(r_{s}\right.$ $0.11-0.24)$.

Table 2. Results of the neurographic measurements.

\begin{tabular}{|c|c|c|c|c|}
\hline \multirow[t]{2}{*}{ Measurement $^{\mathrm{a}}$} & \multicolumn{2}{|c|}{$\begin{array}{c}\text { Dental } \\
\text { technicians } \\
(N=10)\end{array}$} & \multicolumn{2}{|c|}{$\begin{array}{l}\text { Matched } \\
\text { referents } \\
(N=10)\end{array}$} \\
\hline & Mean & SD & Mean & SD \\
\hline \multicolumn{5}{|l|}{$\mathrm{SCV}(\mathrm{m} / \mathrm{s})$ right } \\
\hline $\begin{array}{l}\text { Forearm } \\
\text { Carpal tunnel } \\
\text { Hand }\end{array}$ & $\begin{array}{l}62.75 \\
56.20^{\star *} \\
55.65\end{array}$ & $\begin{array}{l}5.13 \\
7.17 \\
5.37\end{array}$ & $\begin{array}{l}60.25 \\
50.80 \\
55.15\end{array}$ & $\begin{array}{l}3.82 \\
4.75 \\
7.77\end{array}$ \\
\hline \multicolumn{5}{|l|}{ SCV $(\mathrm{m} / \mathrm{s})$ left } \\
\hline $\begin{array}{l}\text { Forearm } \\
\text { Carpal tunnel } \\
\text { Hand }\end{array}$ & $\begin{array}{l}64.15 \\
54.55 \\
58.15\end{array}$ & $\begin{array}{l}5.33 \\
5.37 \\
5.21\end{array}$ & $\begin{array}{l}61.60 \\
51.45 \\
56.55\end{array}$ & $\begin{array}{l}4.62 \\
3.17 \\
7.84\end{array}$ \\
\hline \multicolumn{5}{|l|}{$\begin{array}{l}\text { T-E difference for } \\
\text { digit III (ms) }\end{array}$} \\
\hline $\begin{array}{l}\text { Right } \\
\text { Left }\end{array}$ & $\begin{array}{l}3.11^{*} \\
3.01\end{array}$ & $\begin{array}{l}0.26 \\
0.30\end{array}$ & $\begin{array}{l}2.90 \\
2.96\end{array}$ & $\begin{array}{l}0.35 \\
0.24\end{array}$ \\
\hline
\end{tabular}

a SCV $=$ sensory conduction velocity, $T-E=$ tactile-electric * $P=0.056$, ** $P<0.05$ (Wilcoxon's test for paired data).

Table 3. Results of the perception tests.

\begin{tabular}{|c|c|c|c|c|}
\hline \multirow[t]{2}{*}{ Test } & \multicolumn{2}{|c|}{$\begin{array}{c}\text { Dental } \\
\text { technicians } \\
(N=10)\end{array}$} & \multicolumn{2}{|c|}{$\begin{array}{l}\text { Matched } \\
\text { referents } \\
(N=10)\end{array}$} \\
\hline & Mean & SD & Mean & $S D$ \\
\hline \multicolumn{5}{|c|}{$\begin{array}{l}\text { Vibration threshold } \\
(\mu \mathrm{m})\end{array}$} \\
\hline $\begin{array}{l}\text { Right digit II } \\
\text { Right digit V } \\
\text { Left digit II } \\
\text { Left digit } V\end{array}$ & $\begin{array}{l}2.04^{* *} \\
1.95^{* *} \\
1.58^{* *} \\
1.41\end{array}$ & $\begin{array}{l}1.19 \\
1.50 \\
1.08 \\
1.31\end{array}$ & $\begin{array}{l}0.55 \\
1.08 \\
0.74 \\
1.17\end{array}$ & $\begin{array}{l}0.27 \\
1.76 \\
0.68 \\
1.58\end{array}$ \\
\hline \multicolumn{5}{|c|}{$\begin{array}{l}\text { Cooling threshold } \\
\left({ }^{\circ} \mathrm{C}\right)\end{array}$} \\
\hline $\begin{array}{l}\text { Right digit II } \\
\text { Right digit V } \\
\text { Left digit II } \\
\text { Left digit } V\end{array}$ & $\begin{array}{l}5.2^{\star} \\
5.55^{\star *} \\
4.35^{\star} \\
4.80^{\star}\end{array}$ & $\begin{array}{l}2.43 \\
2.22 \\
2.52 \\
2.59\end{array}$ & $\begin{array}{l}2.95 \\
3.25 \\
2.65 \\
3.65\end{array}$ & $\begin{array}{l}0.69 \\
1.21 \\
0.78 \\
1.86\end{array}$ \\
\hline \multicolumn{5}{|c|}{$\begin{array}{l}\text { Warming threshold } \\
\left({ }^{\circ} \mathrm{C}\right)\end{array}$} \\
\hline $\begin{array}{l}\text { Right digit II } \\
\text { Right digit V } \\
\text { Left digit II } \\
\text { Left digit } V\end{array}$ & $\begin{array}{c}11.35^{\star \star} \\
9.65^{\star} \\
11.70^{* \star \star} \\
9.10^{*}\end{array}$ & $\begin{array}{l}4.03 \\
3.52 \\
2.49 \\
2.46\end{array}$ & $\begin{array}{l}6.55 \\
6.80 \\
6.35 \\
6.75\end{array}$ & $\begin{array}{l}3.80 \\
3.38 \\
2.60 \\
3.67\end{array}$ \\
\hline
\end{tabular}

* $P<0.05,{ }^{* *} P<0.01,{ }^{* * *} P<0.001$ (Wilcoxon's test for paired data). 

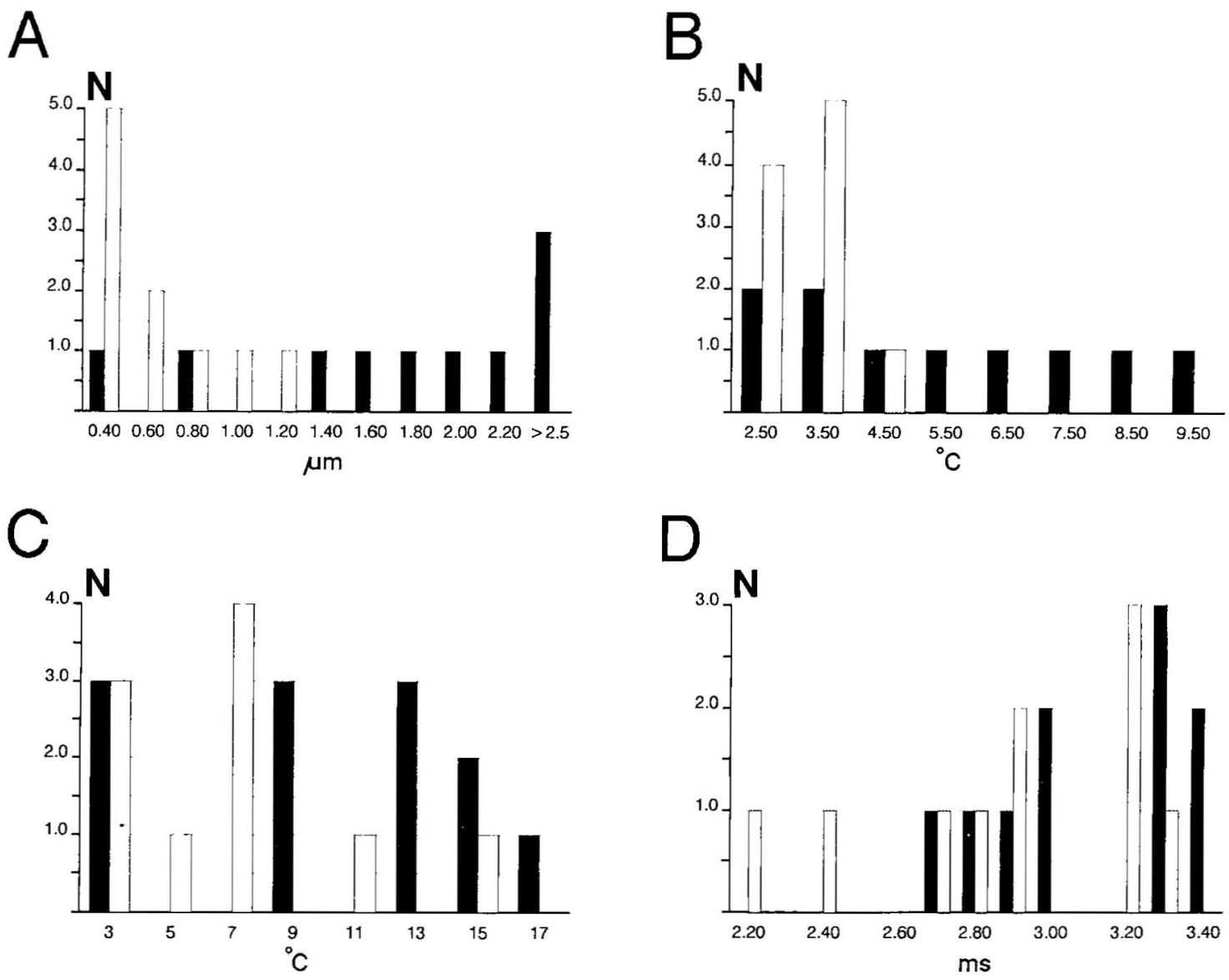

Figure 3. Distribution of the neurophysiological test results for the group of dental technicians (filled columns) and the referents (unfilled columns). (A: vibration threshold measured with the vibrometer on right digit II, B: cooling thresholds measured with the Thermotest ${ }^{(R)}$ on right digit II, C: warming thresholds measured with the Thermotest ${ }^{(t)}$ on right digit II, D: tactile-electric latency difference following stimulation of right digit III)

\section{Discussion}

Our main results were the increases in vibration thresholds and the limits for warming and cooling and an increased difference in the digital nerve response to tactile and electric stimuli at the fingertip. Thus the lesion was not restricted to the group of receptors activated by vibration exposure. In addition thin afferents mediating cold (A-delta) and warmth ( $\mathrm{C}$ fibers) were affected. These categories have no specialized receptor organs, and, since no change in digital nerve conduction velocity was detected, the nerve fiber terminals are the probable targets of the lesion.

The dental technicians complained about clumsiness and loss of fine finger dexterity. Loss of manipulative dexterity has previously been reported among subjects exposed to low-frequency vibration (19). Vibrationinduced neuropathy in the hand has been addressed by several authors, however usually with reference to the occurrence of symptoms similar to the carpal tunnel syndrome $(9,11)$. A decrease in nerve conduction velocities has been demonstrated for the digital and median nerve of patients exposed to low-frequency vibration (12). The dental technicians examined in the present study had normal nerve conduction over the carpal tunnel. Abnormal temperature and vibration thresholds are also reported to be caused by lowfrequency vibration $(6,12)$. Involvement of the digital nerves and the median nerve at the carpal tunnel level requires transmission of the vibration energy through the tissues to this level. Low-frequency vibration generated by tools requiring a full handgrip is absorbed and dampened in the whole hand-wrist system and might therefore even affect the nerves in the carpal tunnel area. However, with the use of grinding instruments utilizing high-frequency vibration, the vibration is damped in the skin, and therefore exposed subjects might develop a lesion pattern different from that of those exposed to low-frequency vibration $(12,20)$. Vibration at higher frequencies has been shown to transmit more energy to the hand than an equal level of lower frequencies weighted according to ISO 5349 $(21,22)$. 
Since dental technicians hold firmly onto their work objects with a forced pinch grip, vibration energy is readily transmitted to the skin. Furthermore skin tissue anoxia might add to the harmful effect of vibration. Resonance in frequencies below $1000 \mathrm{~Hz}$ could also be considered a possible mechanism for the injury.

Our results suggest that high-frequency vibration only induces a distal nerve and/or receptor injury. Low-frequency vibration induces combined distal and proximal nerve lesions in thick myelinated and thin unmyelinated fibers (23). Our own experimental studies showing ultrastructural changes and axonal disorganization primarily in small unmyelinated fibers of nerves in the hind legs of rats exposed to experimental vibration support this mechanism of nerve injury (24).

Vibration skin receptors are very sensitive to vibration in the frequency of 100 to $300 \mathrm{~Hz}$, which is the resonance frequency of the skin (20). Thus vibration above this frequency might not give adequate warning information about noxious vibration exposure. Some dental technicians told that they raised the rotation speed when they experienced finger tingling. Thus they escaped the irritating effect of the vibration but were still exposed to its presumably harmful effects.

The differences in results regarding perception for vibration within one frequency only $(100 \mathrm{~Hz})$ versus a range of frequencies from 8 to $500 \mathrm{~Hz}$ (vibrogram test) may be explained by the uneven distribution of damage in various receptor or nerve fiber groups. Vibration-induced neuropathy may sometimes interfere at first with perception within the higher frequencies (18). If there is an involvement at $500 \mathrm{~Hz}$ but not at $100 \mathrm{~Hz}$, the problem will not be detected by the onefrequency vibrometer technique.

Since the examinations were made after about $20 \mathrm{~h}$ after the last exposure to vibration, the sensory changes should not be acute changes only, but are presumably permanent effects of the exposure to vibration.

The material in this study is small, and there is an overlap between the vibration-exposed group and the referents. However, the results indicate that, while conduction velocity measurements are of limited help for verifying sensory dysfunction in subjects exposed to high-frequency vibration, the described psychophysical techniques described, combined with the calculation of the TE-difference time, might represent valuable new diagnostic tools in this respect. Larger groups must however be studied before one can select proper tests and define normal limits for screening subjects exposed to high-frequency vibration.

According to the 1986 norm of ISO/DIS 5349, vibration harmful for the hand-arm is weighted in frequencies from 6.3 to $1250 \mathrm{~Hz}$. Since acceleration on the dental drills and small work objects is high in the frequencies above $1000 \mathrm{~Hz}$ and reduced tactile sensitivity has been reported for subjects exposed to highfrequency vibra! ion, a standard should be set for frequencies above $1000 \mathrm{~Hz}$.

\section{References}

1. Lundström R, Lindmark A. Effects of local vibration on tactile perception in the hands of dentists. J Low Freq Noise Vib 1982;1:1-11.

2. Lundström R. Effects of local vibration transmitted from ultrasonic devices on vibrotactile perception in the hands of therapists. Ergonomics 1985;28:793-803.

3. Färkkilä M. Vibration induced injury [Editorial]. Br J Ind Med 1986;43:361-2.

4. Pyykkö I. Clinical aspects of the hand-arm vibration syndrome: a review. Scand J Work Environ Health 1986; 12:439-47.

5. Brammer AJ, Taylor W, Lundborg G. Sensorineural stages of the hand-arm vibration syndrome. Scand $J$ Work Environ Health 1987;13:279-83.

6. Ekenvall L, Nilsson BY, Gustavsson P. Temperature and vibration thresholds in vibration syndrome. $\mathrm{Br} \mathrm{J}$ Ind Med 1986;43:825-9.

7. Hirosawa I. Original construction of thermo-esthesiometer and its application to vibration disease. Int Arch Environ Health 1983;52:209-14.

8. Hirosawa I, Watanabe S, Fukuchi Y, Nishiyama K, Hosokawa M. Availability of temperature sense indices for diagnosis of vibration disease. Int Arch Environ Health 1983;52:215-22.

9. Ahlborg G, Voog L, de Laval J, Holm Glad J. Vibrationsexponering och distal kompression av nervus medianus [Vibration exposure and distal compression of the median nerve ("carpal tunnel syndrome")]. Läkartidningen 1982;79:4905-8. (English abstract.)

10. Färkkilä M, Starck $J$, Aatola S, Pyykkö l, Korhonen $O$. Vibration-induced neuropathy among forest workers. Acta Neurol Scand 1985;71:221-5.

11. Wieslander G, Norbäck D, Göthe CJ, Juhlin L. Carpal tunnel syndrome (CTS) and exposure to vibration, repetitive wrist movements, and heavy manual work: a casereferent study. $\mathrm{Br} \mathrm{J}$ Ind Med 1989;46:43-7.

12. Lundborg G, Dahlin LB, Danielsen N, Hansson HA, Necking LE, Pyykkö I. Intraneural edema following exposure to vibration. Scand J Work Environ Health 1987; $13: 326-9$.

13. Gemne G, Pyykkö I, Taylor W, Pelmear PL. The Stockholm Workshop scale for the classification of coldinduced Raynaud's phenomenon in the hand-arm vibration syndrome (revision of the Taylor-Pelmear scale). Scand J Work Environ Health 1987;13:275-8.

14. International Organization for Standardization. Mechanical vibration - guidelines for the measurements and the assessment of human exposure to hand-transmitted vibration. Geneva: International Organization for Standardization, 1986. (ISO-5349-1986.)

15. Kimura $J$. The carpal tunnel syndrome, localization of conduction abnormality within the distal segment of the median nerve. Brain 1979;102:619-35.

16. Goldberg JM, Lindblom U. Standardised method of determining vibratory perception thresholds for diagnosis and screening in neurological investigation. J Neurol Neurosurg Psychiatry 1979;42:793-803.

17. Pratt H, Starr A. Somato-sensory evoked potentials to natural forms of stimulation. In: Craco RQ, BodisWollner I, ed. Evoked potentials. New York, NY: Alan R Liss Inc, 1986:28-34.

18. Lundborg G, Lie-Stenström AK, Sollerman C, Strömberg T, Pyykkö I. Digital vibrogram: a new diagnostic tool for sensory testing in compression neuropathy. $J$ Hand Surg 1986;11 A:693-9.

19. Banister PA, Smith FV. Vibration-induced white fingers and manipulative dexterity. Br J Ind Med 1972;29: $264-7$.

20. Lundström $R$. Local vibrations-mechanical impedance of the human hand's glabrous skin. J Biomech 1984; 17:137-44.

21. Burström L, Lundström R. Mechanical energy absorp- 
tion in human hand-arm exposed to sinusoidal vibrations. Int Arch Occup Environ Health 1988;61:213-6.

22. Lundstrom R. Absorption of mechanical energy in the skin of the human hand while exposed to vibrations. $J$ Low Freq Noise Vib 1986;5:113-20.

23. Ho ST, Yu HS. Ultrastructural changes of peripheral nerve induced by vibration: an experimental study. $\mathrm{Br}$
J Ind Med 1989;46:157-64

24. Lundborg G, Dahlin L-B, Hansson HA, Kanje M, Necking I.E. Vibration exposure and nerve fiber damage. $\mathrm{J}$ Hand Surg (in press).

Received for publication: 2 May 1989 